\title{
Comparison of Field Performance of Different Paddy Transplanters Available in Odisha, India
}

\author{
S. K. Samal, J. N. Mishra, R. R. Pradhan*, P. L. Pradhan and S. K. Mohanty \\ Department of Farm Machinery and Power, College of Agricultural Engineering and \\ Technology, Odisha University of Agriculture and Technology, \\ Bhubaneswar (Odisha), India \\ *Corresponding author
}

\section{A B S T R A C T}

\section{Keywords}

transplanter, missing hill, buried hill, floating hill

Article Info

Accepted: 05 February 2020 Available Online: 10 March 2020
Rice (Oryza sativa) is the most widely consumed staple food especially in Asia which accounts for around $90 \%$ of the world's total rice production. In the country, it is staple food of more than 60 per cent population in India. Among the major paddy producing states, Odisha is one of the major contributor in national production. The agro-climatic condition of Odisha is also suitable for production of rice. It is mostly cultivated by broadcasting and transplanting methods during Kharif and only transplanted during Rabi season. Among these, the latter is getting popularised day by day among the farmers due to more yield. In the state four types of mechanical transplanters have been introduced namely self-propelled eight row, four row walk behind type, four row manual and three row manual paddy transplanter. All these planters have their own limitations and restrictions. Hence, the present study was undertaken to evaluate the transplanters which will be helpful for the farmers to select the suitable transplanter for Odisha condition. The testings were done in Central Farms of Odisha University of Agriculture and Technology, Bhubaneswar. The transplanters were evaluated in terms of planting parameters like missing hills, floating hills and buried hills. The field capacity and, planting efficiency and field efficiency were also measured to recommend a suitable machine. Based on the result, the three row manual transplanter was found to be better in performance on the basis of total unproductive hills $(6.89 \%)$, planting efficiency $(93 \%)$, and field efficiency $(72 \%)$ for Odisha condition.

\section{Introduction}

Rice (Oryza sativa) is the most widely consumed staple especially in Asia which accounts for around 90 per cent of the world's total rice production. India is the world's second largest producer of rice and brown rice, accounting for $20 \%$ of all world rice production and has the largest area under rice cultivation, as it is one of the principal and dominant food crop of more than 60 per cent population in the country. Among the major paddy cultivating states in the country, Odisha is one of them, which agr-climatioc condition and water availability is suitable for production of rice. In the state, out of total net 
cropping area of 90.54 lakh ha, 41.80 lakh ha was under paddy cultivation which includes 21.24 lakh ha of irrigated area. The paddy is mostly cultivated by broadcasting and transplanting methods during Kharif and only transplanted during Rabi season. Based on available irrigation facilities, farmers prefer to transplant the paddy seedlings as it gives better yield than transplanting. Traditional method of rice transplanting is by manual method where a person hold the seedlings and put it in the field manually. This method is very tedious and very time-consuming process requiring 250-300 man-h per ha. In Odisha, rice transplanting is generally done by women labours using root-washed seedlings. It has been observed that during peak season of transplanting, there is acute shortage of labour which normally results delaying of transplanting of paddy, thereby reducing yield. Irrespective of huge labour requirement, plant to plant and row to row spacing is not achieved and hence mechanical weeding is not possible. Optimum plant density and timeliness of operation in paddy is considered essential for maximum paddy yield which could be possible if dependence on hired labour is minimized. Since, long, mechanical transplanting using self-propelled rice transplanter has been considered as the most promising option because it saves labour to the tune of 90 per cent and operating time 80 percent (Ojha and Michael, 2003) of that required in manual transplanting, minimizes stress and drudgery, ensures timely transplanting and attains optimum plant density contributing to higher productivity. Mechanization increases land productivity by timely completion of farm operations. It increases labour productivity by reducing drudgery of human and animals. It increases production by precision and efficient placement of inputs such as seed, fertilizer, chemicals. Mechanization decreases cost of production by reducing labour needed for particular operation and economy of power and other inputs. Therefore, this study was undertaken to study the mechanical performance and suitability of the different commercially available paddy transplanters for the Eastern region of Odisha. Four types of paddy transplanters were considered for the study viz. eight row self-propelled paddy transplanter, four row walk behind type paddy transplanter and three row manual paddy transplanter.

\section{Materials and Methods}

The study was undertaken at Research farm of Department of Farm Machinery and Power, OUAT during Kharif seasons of 2017 and 2018. In this experiment field performance evaluation of mainly four types of paddy transplanters were done viz. Eight row selfpropelled paddy transplanter (Yanji Shakti), self-propelled four row walk behind type, Four Row Manual type (CRRI) and three row manual transplanter (OUAT). The technical specification of the three transplanters selected for the study is given in Table 1. Mat type seedlings were used in all the transplanters.

\section{Self-propelled eight row paddy transplanter}

Self-propelled eight row paddy transplanter is an 8 row riding type machine operated by a $2.94 \mathrm{~kW}$ diesel engine. The machine needs a power transmission system, handle for operation, main frame and rice transplanting tray, float and transplanting unit. It has lugged wheel and the weight of the machine rests on the lugged wheel and float at the time of transplanting in puddled field. The same lugged wheel is replaced by pneumatic wheel power transportation. Power from the engine is transmitted to front wheels through a gear train and to the transmission housing of transplanting unit through universal shaft. The machine has 3 forward gears ( 2 for field and 1 
for road). No reverse gear is provided. Row to row spacing is $23.8 \mathrm{~cm}$. and plant to plant spacing is adjustable (14 and $17 \mathrm{~cm}$.). Two settings are provided for adjusting the number of hills transplanted $/ \mathrm{m}^{2}$. Transplanting depth is also adjustable. A view of machine operation is shown in Fig.1 and its brief specification is given in Table-1.

\section{Self-propelled walk behind type paddy transplanter}

Self-propelled walk behind type paddy transplanter is a 4 row walk behind machine operated by a $3.2 \mathrm{~kW}$ petrol engine. The machine consisted of power transmission system; handle for steering the machine, mainframe and rice transplanting tray-float and two pairs of transplanting units.It has only two lugged wheels and float at the time of transmission housing of transplanting unit through universal shaft. The machine has one forward gear and one reverse gear. Row to row spacing is $30.0 \mathrm{~cm}$ and four numbers of settings are provided for plant to plant spacing $(12,14,18$ and $21 \mathrm{~cm})$. There are also provisions for adjusting the no. of hills tranplanter per sq. meter. and transplanting depth. A view of machine in operation is shown in Fig. 2 and its brief specification is given in Table1.

\section{Four row manual paddy transplanter (CRRI)}

A manually operated four-row rice transplanter developed at CRRI, Cuttack and commercially manufactured by M/S Sidheswar Engineering, Bidyadharpur, Cuttack(Orissa) was used for the study. Salient features of the machine are given in Table 1. This machine has two floats, a main frame assembly for supporting the seedlings tray, mat pusher, tray movement mechanism, picker bar assembly and handle. Here row-torow spacing is $24 \mathrm{~cm}$ whereas plant-to-plant spacing can be changed as per the requirement. The machine is pull-type and transplants mat-type seedlings in four rows in a single pass. Two floats facilitate the transplanter to slide over the puddle surface. The tray containing mat-type seedlings for 4rows is moved sideways by a tray movement mechanism, which converts rotary motion of the handle through chain into linear motion of the rod connected to the seedling tray having provision to reverse the direction of movement of tray after it reaches the extreme position at one end. Fixed opening type fingers are attached with the transplanting arm of the machine.

\section{Manual three row paddy transplanter}

Manual three row paddy transplanter is a machine operated one and requires one person for pulling. It uses mat type seedling with a row spacing of $24 \mathrm{~cm}$. The hill to hill distance is adjustable. Three mats are placed on the machine tray by pushing the handle down. The seedlings from the mats are picked up and transplanted in the puddled soil. The handle is then pulled backward by the operator to retract the pickers and move the machine for next planting stroke. The cycle is repeated to transplant another three hills. Each time the handle is pushed downwards it is required to ensure that seedling tray moves laterally so that the seedling will be picked by the pickers during the next cycle. With this machine transplanting can be done with a rate $0.016 \mathrm{ha} / \mathrm{h}$ with the help of two operators.

\section{Method for raising mat seedlings}

Generally, the farmers are used to raise the root wash type seedlings directly in the field for traditional hand transplanting. But the mat type seedlings are raised in pre-fabricated GI trays in the backyard or on polythene sheets in the field. For this purpose, loamy soil and FYM mixture is prepared and spread over the 
trays or on polythene sheet up to $1-1.5 \mathrm{~cm}$. Prior to that the mixture of soil and FYM is screened properly by sieve to remove the clods, stones, roots and other foreign materials present in the mixture. Before that the seeds are to be soaked in fresh water for 24 hours in the room temperature followed by wrapping them in wet jute sack for 12 hours. Finally, the little sprouted germinated seeds are put over the soil mixture and thin layer of soil is spread over the sprouted seeds. Seed rate of $35-38 \mathrm{~kg} / \mathrm{ha}$ is required for preparation of mat type seedlings as compared to 70-80 $\mathrm{kg} / \mathrm{ha}$ in case of manual transplanting. The growth of seedlings is monitored by spraying water regularly by a rose cane with a preferable temperature of $25-30^{\circ}$ in the nursery for next 16-22 days till they become suitable for transplanting. Sometimes the sprouted seeds or seedling has to be kept under protection under mosquito nets or straw where the activities of rodent animals or birds are higher. It is observed at the time of transplanting the seedlings height is more in case of traditional seedlings as compared to mat type seedlings as they are raised directly in the field.

\section{Results and Discussion}

The results obtained from the present study have been summarized in Table 2. Missing hills occurred may be primarily due to the entanglement of roots, non-uniformity of seedlings in the mat and buckling of mats. Maximum missing hills permissible is $8 \%$. It was found minimum for self-propelled walk behind four row transplanter $(2.5 \%)$ followed by four row manual transplanter (CRRI) (4\%) three row manual transplanter(4.5\%) and selfpropelled eight row transplanter(6.4\%).

Table.1 Technical specifications of different transplanters

\begin{tabular}{|c|c|c|c|c|c|}
\hline $\begin{array}{l}\text { Sl. } \\
\text { No. }\end{array}$ & Specifications & $\begin{array}{l}\text { Self-propelled } \\
\text { eight row paddy } \\
\text { transplanter } \\
\text { (Yanji Shakti) }\end{array}$ & $\begin{array}{c}\text { Self-propelled } \\
\text { four row walk } \\
\text { behind type }\end{array}$ & $\begin{array}{l}\text { Four row } \\
\text { manual } \\
\text { paddy } \\
\text { transplanter } \\
\text { (CRRI) }\end{array}$ & $\begin{array}{l}\text { Three row } \\
\text { manual } \\
\text { transplanter } \\
\text { (OUAT) }\end{array}$ \\
\hline 1 & Type of machine & $\begin{array}{l}\text { Power operated } \\
2.94 \mathrm{KW} \text { air } \\
\text { cooled engine }\end{array}$ & $\begin{array}{l}\text { Petrol engine, } \\
3.20 \mathrm{~kW}\end{array}$ & Manual & Manual \\
\hline 2 & $\begin{array}{l}\text { Type of nursery } \\
\text { used }\end{array}$ & Mat type & Mat type & Mat type & Mat type \\
\hline 3 & Type of Steering & Mechanical & Handle type & N/A & N/A \\
\hline 4 & $\begin{array}{l}\text { Overall dimensions } \\
\mathrm{L} \times \mathrm{W} \times \mathrm{H}(\mathrm{cm})\end{array}$ & $241 \times 229 \times 120$ & $910 \times 565 \times 655$ & $127 \times 117 \times 62$ & $600 \times 600 \times 940$ \\
\hline 5 & Finger type & Fixed type & Fixed type & Fixed type & Fixed type \\
\hline 6 & Number of rows & 8 & 4 & 4 & 3 \\
\hline 7 & Row spacing (cm) & 23.8 & 30 & 24 & 24 \\
\hline 8 & $\begin{array}{l}\text { Hill to hill } \\
\text { distance }(\mathrm{cm})\end{array}$ & $12-14$ & Adjustable & Adjustable & Adjustable \\
\hline
\end{tabular}


Table.2 Results of field testing of different transplanters

\begin{tabular}{|l|c|c|c|c|c|}
\hline \multicolumn{1}{|c|}{ Parameters } & $\begin{array}{c}\text { Self- } \\
\text { propelled } \\
\text { eight row } \\
\text { transplanter }\end{array}$ & $\begin{array}{c}\text { Self-propelled } \\
\text { walk behind } \\
\text { four row } \\
\text { transplanter }\end{array}$ & $\begin{array}{c}\text { Four row } \\
\text { manual } \\
\text { transplanter } \\
\text { (CRRI) }\end{array}$ & $\begin{array}{c}\text { Three row } \\
\text { manual } \\
\text { transplanter } \\
\text { (OUAT) }\end{array}$ & $\begin{array}{c}\text { Farmer's } \\
\text { practice } \\
\text { (random } \\
\text { transplanting) }\end{array}$ \\
\hline Number of seedlings/hill & $2-5$ & $2-5$ & $2-4$ & $2-4$ & $2-3$ \\
\hline Hill to hill Distance, mm & $12-14$ & Adjustable & Adjustable & Adjustable & Adjustable \\
\hline $\begin{array}{l}\text { Number of hills } \\
\text { Planted/m }\end{array}$ & 26.26 & 23.80 & 30.86 & $30-35$ & $26-28$ \\
\hline Missing hills, \% & 6.46 & 2.51 & 4.03 & 4.58 & - \\
\hline Floating hills, \% & 1.35 & 1.25 & 1.53 & 1.54 & - \\
\hline Buried hills, \% & 2.21 & 3.37 & 2.53 & 0.89 & - \\
\hline Total unproductive hills, & 9.95 & 7.05 & 8.00 & 6.89 & \\
\hline \% & & & & & \\
\hline Planting efficiency, \% & 89 & 92 & 76.56 & 93 & - \\
\hline Field capacity, ha/h & 0.182 & 0.125 & 0.025 & 0.016 & 0.004 \\
\hline Field efficiency, \% & 68.2 & 70.6 & 70.76 & 72 \\
\hline Man-hours/ha used & 5 & 6.25 & 40 & 62.5 \\
\hline
\end{tabular}

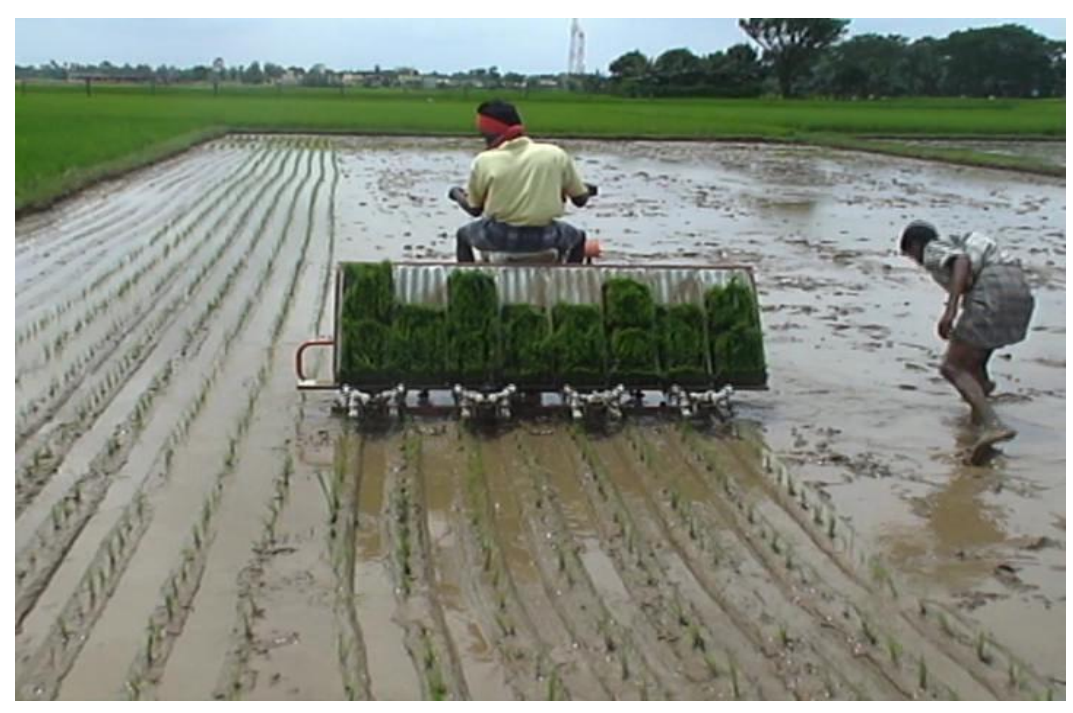

Fig.1 Self-propelled eight row paddy transplanter 

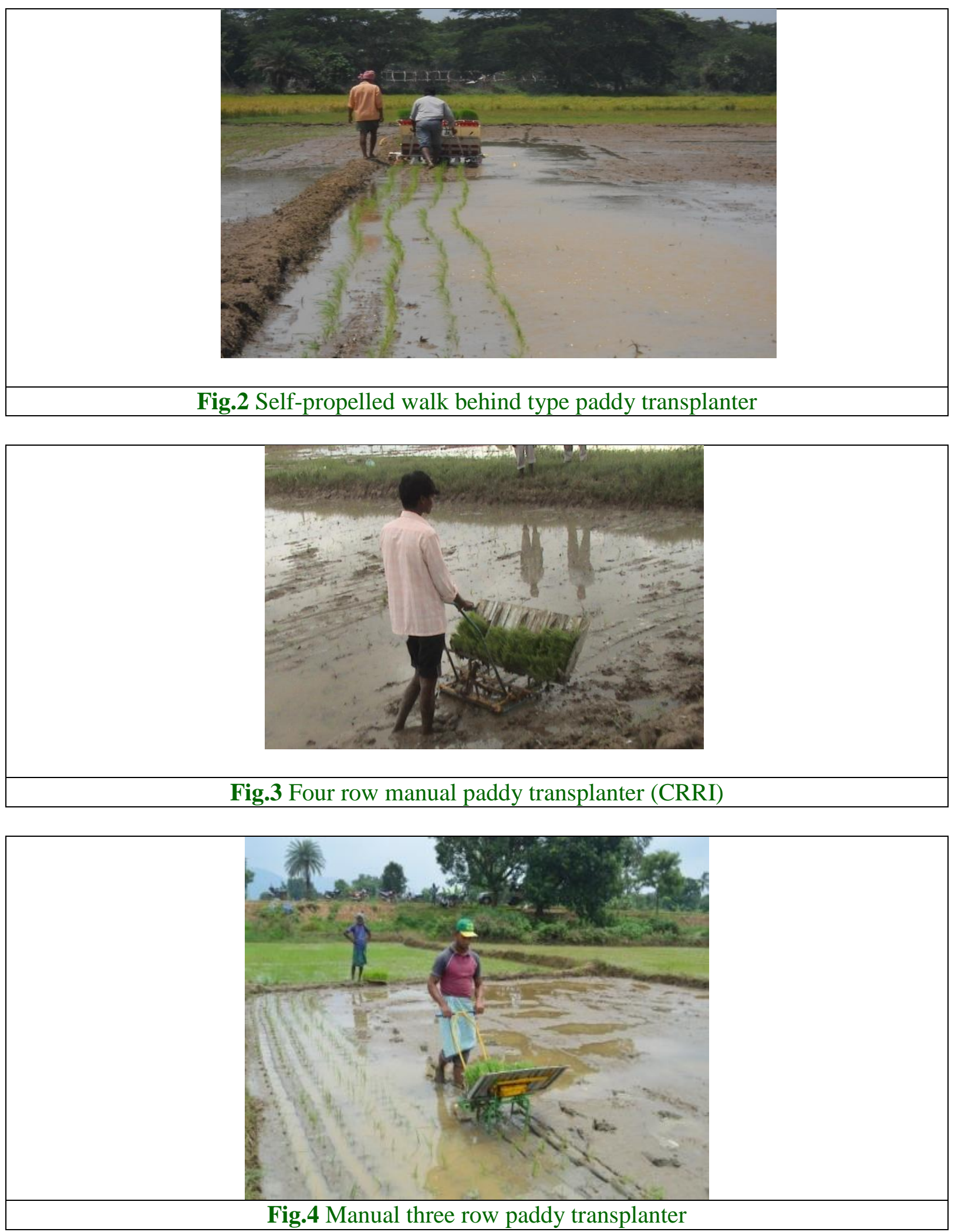

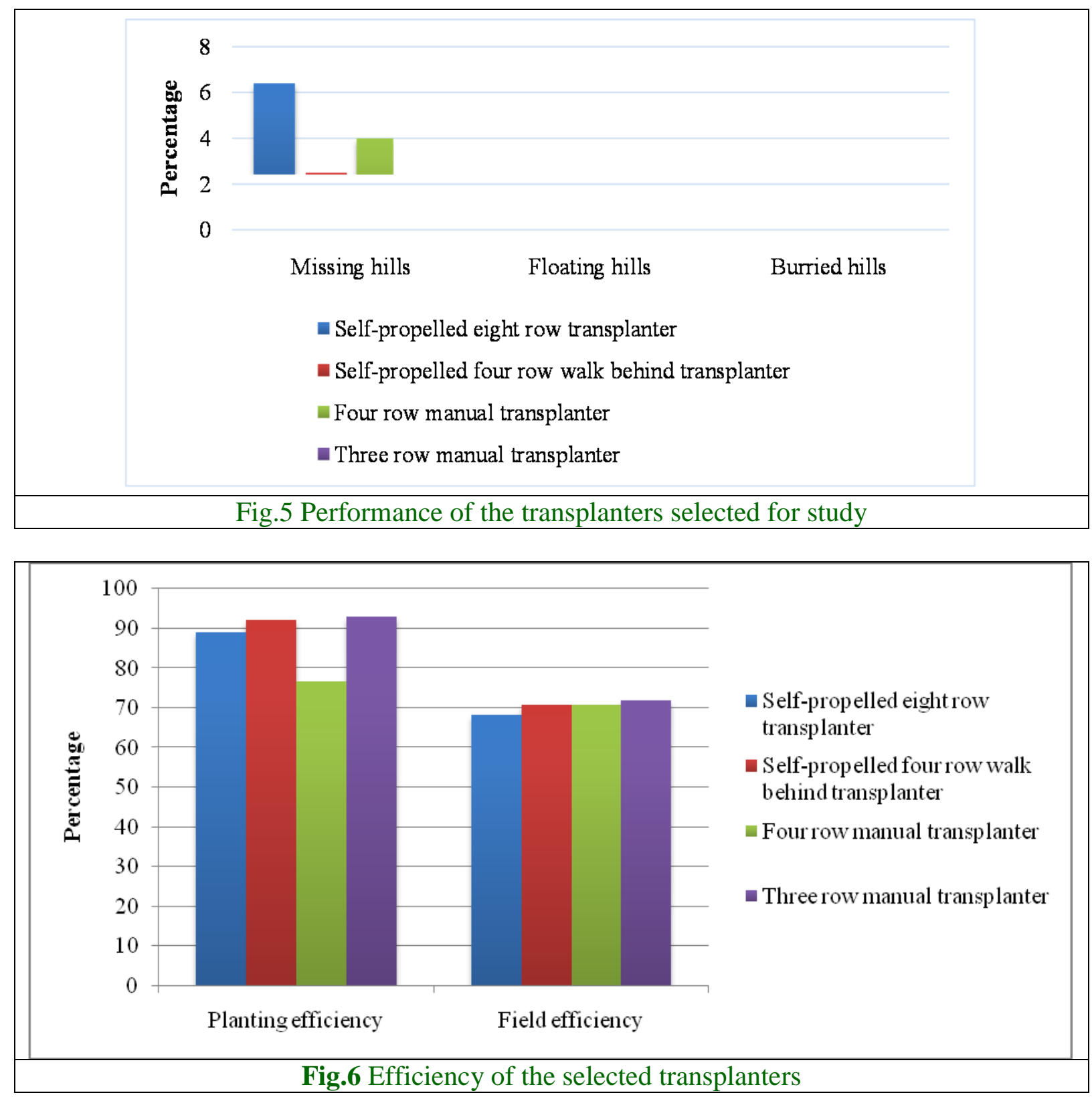

Floating hills may have occurred due to poor anchorage of seedlings in the soil. Maximum floating hills permissible is $3 \%$. It was found to be minimum in case of self-propelled walk behind four row transplanter $(1.25 \%)$ followed by self-propelled eight row $(1.35 \%)$, three row manual (1.5\%) and four row manual transplanter (1.5\%)respectively. Buried hill occurred due to the flow of the soil along with the transplanter due to higher float sinkage. Percentage of buried hills was maximum in case of self-propelled walk behind four row transplanter(3.3\%) followed by four row manual transplanter $(2.5 \%)$, self-propelled eight row transplanter(2.2\%) and three row manual transplanter(0.89\%)(Fig.5).

Planting efficiency was $89 \%, 92 \%, 76.56 \%$ and $93 \%$ in case of self-propelled eight row, self-propelled walk behind four row, four row manual and three row manual transplanter respectively. The field capacity and field efficiency were found to be as follows for self-propelled eight row transplanter 
$(0.18 \mathrm{ha} / \mathrm{h}, 68.2 \%)$,self-propelled walk behind four row transplanter $(0.12 \mathrm{ha} / \mathrm{h}, 70.6 \%)$, four row manual transplanter $(0.025 \mathrm{ha} / \mathrm{h}, 70.76 \%)$ and for, and three row manual transplanter (0.016 ha/h,72\%) respectively (Fig.2).

From the above study, the following conclusions were drawn:

1. Three row manual transplanter was found to be better in performance on the basis of total unproductive hills (6.89\%), planting efficiency (93\%), and field efficiency $(72 \%)$.

2. Training of operator was found necessary for using manually operated 4 row transplanter (CRRI model), to maintain the required hill to hill distance. The average values of percentage of missing hills, floating hills, buried hills, field capacity, planting efficiency and field efficiency observed were $4 \%, 1.5 \%, 2.5 \%$, $0.025 \mathrm{ha} / \mathrm{h}, 76.56 \%$ and $\quad 70.76 \%$ respectively.

3. In self-propelled four row transplanter the average values of percentage of missing hills, floating hills, buried hills, field capacity, planting efficiency and field efficiency observed to be $2.5 \%, 1.25 \%$, $3.3 \%, \quad 0.12 \mathrm{ha} / \mathrm{h}, 92 \%, \quad$ and $\quad 70.6 \%$ respectively.

In Self-propelled eight row transplanter the average values of field capacity, unproductive hills, planting efficiency and field efficiency observed were $0.18 \mathrm{ha} / \mathrm{h}, 9.95 \%, 89 \%$ and $68.2 \%$ respectively.

\section{References}

B.K. Yadav and B.S. Kherawat (2013). Selective mechanization for enhancing productivity of rice cultivation. Internat. J. of Agril.Engg. 6(1): 289-290

Behera BK, Varshney BP and Goel AK (2009). Effect of puddling on puddled soil characteristics and performance of selfpropelled transplanter in rice crop. Agril. Engg. Int.: the CIGR E journal 10: 1-18

Das FC (2009). Report on status and prospects of mechanisation in rice. Rice Knowledge Management Portal pp.1 24

Das, F.C. (2012). Status and prospects of mechanization in rice. Rice knowledge management portal. Available at http:// www.rkmp.co.in.

Dixit A, Khurana R, Singh $J$ and Singh G (2007). Comparative performance of different paddy transplanters developed in India - A review. Agril. Reviews 28(4): 262- 269

Goel, A.K, Swain, S. and Debaraj, B. (2008). Effect of seedling age on performance of rice transplanter.journal of agricultural Mechanization in Asian Africa \& Latin America, 40 (3) : 41- 46.

Kumar A, Nayak AK, Pani DR and Das BS (2017). Physiological and morphological responses of four different rice cultivars to soil water potential-based deficit irrigation management strategies. Field Crops Research 205: 78-94

Selvan MM, Annamalai SJK, Thavaprakash N and Ananathakrishnan D (2014). Design and development of three row improved pull-type rice transplanter for small farmers. The Indian J.of Agril. Sci. 84: 130-135

Singh S and Vatsa DK (2006). Performance evaluation of PAU manual paddy transplanter in hills of Himachal Pradesh. Agril. Engg. Today 30 (3): 19-25

Uttam Kumar and Anil Kumar (2012). Performance evaluation of manually operated four-row rice transplanter in Jharkhand (India). SKUAST J. Res.14: 59-66

Yadav R, Patel M, Shukla SP and Pund S (2007). Ergonomic evaluation of manually operated six-row paddy transplanter. Int. Agril. Engg. J. 16(3-4): 147-157 
How to cite this article:

Samal. S. K., J. N. Mishra, R. R. Pradhan, P. L. Pradhan and Mohanty. S. K. 2020. Comparison of Field Performance of Different Paddy Transplanters Available in Odisha. Int.J.Curr.Microbiol.App.Sci. 9(03): 992-1000. doi: https://doi.org/10.20546/ijcmas.2020.903.117 